\title{
Data report: Quaternary calcareous nannofossil datums and biochronology in the North Atlantic Ocean, IODP Site U1308'
}

\author{
Tokiyuki Sato, ${ }^{2}$ Shun Chiyonobu, ${ }^{3}$ and David A. Hodell ${ }^{4}$
}

\begin{abstract}
Chapter contents
Abstract...................... Introduction $\ldots \ldots \ldots \ldots \ldots \ldots \ldots \ldots \ldots$

Samples and methods..............

Results.................... 2

Remarks on stratigraphic position of datums . 2

Conclusion................... 3

Acknowledgments.............. 3

References................... 3

Figures.................... 5

Table .................... 9
\end{abstract}

${ }^{1}$ Sato, T., Chinyonobu, S., and Hodell, D.A., 2009. Data report: Quaternary calcareous nannofossil datums and biochronology in the North Atlantic Ocean, IODP Site U1308. In Channell, J.E.T., Kanamatsu, T., Sato, T., Stein, R., Alvarez Zarikian, C.A., Malone, M.J., and the Expedition 303/306 Scientists, Proc. IODP, 303/306: College Station, TX (Integrated Ocean Drilling Program Management International, Inc.).

doi:10.2204/iodp.proc.303306.210.2009

${ }^{2}$ Institute of Applied Earth Sciences, Faculty of Engineering and Resource Science, Akita

University, 1-1 Tegata-gakuencho, Akita 010-8502, Japan. toki@keigo.mine.akita-u.ac.jp

${ }^{3}$ Institute of Geology and Paleontology, Graduate School of Science, Tohoku University, AramakiAoba, Sendai 980-8578, Japan.

${ }^{4}$ Department of Geological Sciences, University of Florida, 214 Williams Hall, PO Box 112120,

Gainesville FL 32611, USA.

\section{Abstract}

We studied high-resolution Quaternary calcareous nannofossil biostratigraphy to clarify the relationship between nannofossil events and oxygen isotope stratigraphy using the continuous sediment sequence from Integrated Ocean Drilling Program Site U1308 in the North Atlantic Ocean. Results indicate that some nannofossil events found in the section, such as the last occurrences of Reticulofenestra asanoi and Gephyrocapsa spp. (large), are located in a different stratigraphic position compared to previous studies. We also clarify the critical stratigraphic positions of both the first occurrence of Emiliania huxleyi and the last occurrence of Pseudoemiliania lacunosa, which occur just below the highest peaks of each marine isotope Stage 8 and 12 .

\section{Introduction}

Quaternary calcareous nannofossil datums and their chronostratigraphic framework have been discussed over the last 20 y mainly based on their correlation to magnetostratigraphy (Raffi and Rio, 1979; Rio, 1982; Takayama and Sato, 1987) or to oxygen isotope stages (Thierstein et al., 1977; Wei, 1993; Raffi et al., 1993; Raffi, 2002). These studies indicate that Quaternary nannofossil datums show a small diachroneity between different latitudes. However, some studied sections were not completely continuous because of coring problems or were not suitable for high-resolution study because of low sedimentation rate.

In 2005, drilling sites of Integrated Ocean Drilling Program (IODP) Expedition 303 in the North Atlantic Ocean were chosen to recover cores that would yield complete and continuous records of millennial-scale environmental variability. This means that the core samples from Expedition 303 are suitable for study of millennial climate variability throughout the Quaternary. The main purpose of this study is to clarify the detailed relationship between Quaternary nannofossil events and oxygen isotope stratigraphy using the continuous Quaternary sedimentary sequence from Site U1308 in the North Atlantic Ocean (Fig. F1).

\section{Samples and methods}

Although core catcher samples were used for lower Quaternary samples below the Cobb Mountain Subchron, samples above the 
Cobb Mountain Subchron were collected at $\sim 5 \mathrm{~cm}$ intervals from the upper Quaternary sequences for discussion of the relationship between oxygen isotope stratigraphy and nannofossil datums. The depth of each sample is calculated to meters composite depth (mcd) based on core to core correlation. As the Quaternary sedimentation rate of this site is 7.6 $\mathrm{cm} / \mathrm{k} . \mathrm{y}$. (Channell et al., 2006), the studied intervals $(\sim 5 \mathrm{~cm})$ correspond to $650 \mathrm{y}$. Samples were prepared by smear slide methods and were studied under a Zeiss Axio Imager polarizing microscope under $1600 \times$ magnification.

\section{Results}

A total of 11 uppermost Pliocene to Quaternary nannofossil datums are detected in the Site U1308 section (Table T1; Figs. F2, F3). Based on the datum numbers of Sato and Takayama (1992), Datum 2, the first occurrence of Emiliania huxleyi, which defines the Zone NN20/NN21 boundary of Martini's zonation, is found at $16.88-16.93$ mcd. Datum 3, the last occurrence of Pseudoemiliania lacunosa, which correlates to the Zone NN19/NN20 boundary, is detected between 28.14 and 28.19 mcd. Because Helicosphaera inversa occurs rarely throughout the section, Datums 1 and 4 were not recognized here. Datums 5 and 7, the last and first occurrences of Reticulofenestra asanoi, are respectively found at 55.47-55.52 and 80.28-80.33 mcd. Datums 6 and 8, the first occurrence of Gephyrocapsa parallela and last occurrence of the large form Gephyrocapsa spp., are situated at 66.40-66.45 and 84.56-84.86 mcd, respectively. Datums 9 (last occurrence of Helicosphaera sellii; 84.86$90.16 \mathrm{mcd}$ ), 10 (first occurrence of large Gephyrocapsa spp.; 100.59-103.52 mcd), 11 (first occurrence of Gephyrocapsa oceanica; 123.07-131.27 mcd), 12 (first occurrence of Gephyrocapsa caribbeanica; 131.27-132.74 mcd), and 13 (last occurrence of Discoaster brouweri; $114.51-153.29 \mathrm{mcd}$ ) are situated in the uppermost Pliocene to lower Pleistocene interval.

Based on the stratigraphic position of these datums at Site U1308, we also correlate the datums to magnetostratigraphy, which was studied by Channell et al. (2006) (Fig. F2). Both Datums 2 and 3 are traceable to the Brunhes Chron. Datum 5 is situated between the Brunhes Chron and Jaramillo Subchron of the Matuyama Chron, and Datum 6 is traceable to the top of the Jaramillo Subchron. Datum 7 is found between the Jaramillo and Cobb Mountain Subchrons, and Datum 8 is situated within the Cobb Mountain Subchron of the Matuyama Chron (Fig. F2). Datums 9-12 are present between the Cobb Mountain and the Olduvai Subchrons in the Matuy- ama Chron. Datum 13 is detected just below the Olduvai Subchron (Fig. F2).

We also compared the nannofossil datum events with oxygen isotope stratigraphy (Fig. F2). Datums 2 and 3 are respectively situated in marine isotope Stage (MIS) 8 and 12. Both datums are situated just before the highest peak of the respective MIS. Datums 5 and 6 are respectively found in MIS 21 and 27, and Datums 7, 8, 9, and 10 are found in MIS 34, 35,38 , and 44, respectively. Ages of nannofossil datums and the relationship between nannofossil biostratigraphy, magnetostratigraphy, and oxygen isotope stratigraphy are summarized in Figure F3 and Table T1.

\section{Remarks on stratigraphic position of datums}

Takayama and Sato (1987) identified 11 Quaternary nannofossil datums at Deep Sea Drilling Project Sites $606,607,608,609,610$, and 611, located between $37^{\circ} \mathrm{N}$ and $53^{\circ} \mathrm{N}$ in the North Atlantic Ocean. They described that 9 of 11 Quaternary nannofossil datums were traceable to all sites in the North Atlantic Ocean and that the stratigraphic positional relationship of each nannofossil datum to magnetostratigraphy were invariable. Site U1308 is a reoccupation of Site 609.

Site U1308 is suitable for high-resolution study to clarify the relationship between magnetostratigraphy, oxygen isotope stratigraphy, and calcareous nannofossil biostratigraphy in detail (Figs. F2, F3). The relationship between magnetostratigraphy, oxygen isotope stratigraphy, and calcareous nannofossil biostratigraphy has been previously discussed based on study of deep-sea sediments (Thierstein et al., 1977; Wei, 1993; Raffi et al., 1993; Raffi, 2002). Raffi (2002) and Raffi et al. (2006) summarized the biochronology of nannofossil events and discussed the synchroneity of nannofossil datum events.

Although our results are almost the same as those by Raffi et al. (2006), some datums such as Datums 5 and 8 are biochronostratigraphically different from those described by Raffi et al. (2006).

\section{Datum 8: last occurrence of Gephyrocapsa spp. (large)}

Gephyrocapsa spp. (large) in this study is correlated to large Gephyrocapsa spp. by Raffi (2002) and Raffi et al. (2006) and Gephyrocapsa spp. A-B by Wei (1993). Raffi (2002) correlated the position of Datum 8 to MIS 37-38 below the Cobb Mountain Subchron. Our results, however, indicate that Datum 8 is found 
within the Cobb Mountain Subchron at Site U1308 and is correlated to MIS 35. This correlates well with results from Sites 609, 610, and 611 (Takayama and Sato, 1987) and from Quaternary sequences in Japan (Sato and Takayama, 1992).

\section{Datum 5: last occurrence of Reticulofenestra asanoi}

Although the stratigraphic position of Datum 5, last occurrence of $R$. asanoi at Site U1308, is correlated to the lowest peak of MIS 21 in this study, its position by Wei (1993) and Raffi (2002) is traced to MIS 22. Raffi (2002) summarized the biochronological problems introduced by the influence of regional environmental conditions on diachronous placement of biological datum events. However, Datum 5 was interpreted as being abrupt and consistently isochronous and is associated with the mid-Pleistocene revolution (Raffi, 2002). Our results indicate that the presence of a small difference in chronostratigraphic position of this datum may reflect the influence of regional environmental conditions.

\section{Datums 2 and 3: first occurrence of Emiliania huxleyi and last occurrence of Pseudoemiliania lacunosa}

Datums 2 and 3 in this study occur in MIS 8 and 12, respectively. These results are the same as those of Thierstein et al. (1977), Wei (1993), and Raffi (2002). Furthermore, our high-resolution study also clarifies the critical stratigraphic positions of both datums, which are situated just before the highest peaks of each MIS (Fig. F2). Datum 2 is at $16.88-16.93 \mathrm{mcd}$, $0.82 \mathrm{~m}$ below the highest peak of MIS 8. Datum 3 is also traceable to $28.14-28.19 \mathrm{mcd}, 0.41 \mathrm{~m}$ below the highest peak of MIS 12. These differences between MIS peak and datum level are calculated as $12.6 \mathrm{k} . \mathrm{y}$. (Datum 2) and 16.2 k.y. (Datum 3) (Fig. F4).

\section{Conclusion}

We clarify the critical relationship between nannofossil biostratigraphy, oxygen isotope stratigraphy and magnetostratigraphy based on high-resolution studies of the Quaternary sequence of Site U1308 in the North Atlantic Ocean. The last occurrence of Gephyrocapsa spp. (large) is situated within the Cobb Mountain Subchron, the same as results by Takayama and Sato (1987), and is traceable to MIS 35. The first occurrence of $E$. huxleyi and last occurrence of $P$. lacunosa are correlated to the stratigraphic posi- tion just before the highest peak of MIS 8 and 12, respectively.

\section{Acknowledgments}

Samples for this study were provided by the Integrated Ocean Drilling Program. We are grateful to many scientific staff on board the JOIDES Resolution.

\section{References}

Channell, J.E.T., Sato, T., Kanamatsu, T., Stein, R., Malone, M., Alvarez-Zarikian, C., and the IODP Expeditions 303 and 306 Scientists, 2006. IODP Expeditions 303 and 306 monitor Miocene-Quaternary climate in the North Atlantic. Sci. Drill., 2:4-10. doi:10.2204/ iodp.sd.2.01.2006

Raffi, I., 2002. Revision of the early-middle Pleistocene calcareous nannofossil biochronology (1.75-0.85 Ma). Mar. Micropaleontol., 45(1):25-55. doi:10.1016/S03778398(01)00044-5

Raffi, I., Backman, J., Fornaciari, E., Pälike, H., Rio, D., Lourens, L., and Hilgen, F., 2006. A review of calcareous nannofossil astrobiochronology encompassing the past 25 million years. Quat. Sci. Rev., 25(23-24):3113-3137. doi:10.1016/j.quascirev.2006.07.007

Raffi, I., Backman, J., Rio, D., and Shackleton, N.J., 1993. Plio-Pleistocene nannofossil biostratigraphy and calibration to oxygen isotope stratigraphies from Deep Sea Drilling Project Site 607 and Ocean Drilling Program Site 677. Paleoceanography, 8(3):387-408. doi:10.1029/ 93PA00755

Raffi, I., and Rio, D., 1979. Calcareous nannofossil biostratigraphy of DSDP Site 132_Leg 13 (Tyrrhenian SeaWestern Mediterranean). Riv. Ital. Paleontol. Stratigr., 85:127-172.

Rio, D., 1982. The fossil distribution of coccolithophore genus Gephyrocapsa Kamptner and related Plio-Pleistocene chronostratigraphic problems. In Prell, W.L., Gardner, J.V., et al., Init. Repts. DSDP, 68: Washington, DC (U.S. Govt. Printing Office), 325-343. doi:10.2973/ dsdp.proc.68.109.1982

Sato, T., and Takayama, T., 1992. A stratigraphically significant new species, Reticulofenestra asanoi (calcareous nannofossil). In Ishizaki, K., and Saito, T. (Eds.), Centenary of Japanese Micropaleontology: Tokyo (Terra Sci. Publ.), 457460. http://www.terrapub.co.jp/e-library/cjm/pdf/ 0457.pdf

Takayama, T., and Sato, T., 1987. Coccolith biostratigraphy of the North Atlantic Ocean, Deep Sea Drilling Project Leg 94. In Ruddiman, W.F., Kidd, R.B., Thomas, E., et al., Init. Repts. DSDP, 94: Washington, DC (U.S. Govt. Printing Office), 651-702. doi:10.2973/

dsdp.proc.94.113.1987 
Thierstein, H.R., Geitzenauer, K.R., Molfino, B., and Shackleton, N.J., 1977. Global synchroneity of late Quaternary coccolith datum levels validation by oxygen isotopes. Geology, 5(7):400-404. doi:10.1130/ 0091-7613(1977)5<400:GSOLQC>2.0.CO;2

Wei, W., 1993. Calibration of upper Pliocene-lower Pleistocene nannofossil events with oxygen isotope stratigra- phy. Paleoceanography, 8(1):85-99. doi:10.1029/ 92PA02504

Initial receipt: 29 September 2008

Acceptance: 10 September 2009

Publication: 25 November 2009

MS 303306-210 
Figure F1. Location map of Site U1308 analyzed in this study. Arrows indicate major deepwater flows. DSOW = Denmark Strait Overflow Water, NGS = Norwegian Greenland Sea, ISOW = Iceland Sea Overflow Water, WTRO = Wyville Thomson Ridge Overflow, GFZ = Charlie Gibbs Fracture Zone, LSW = Labrador Sea Water, LDW = Lower Deep Water.

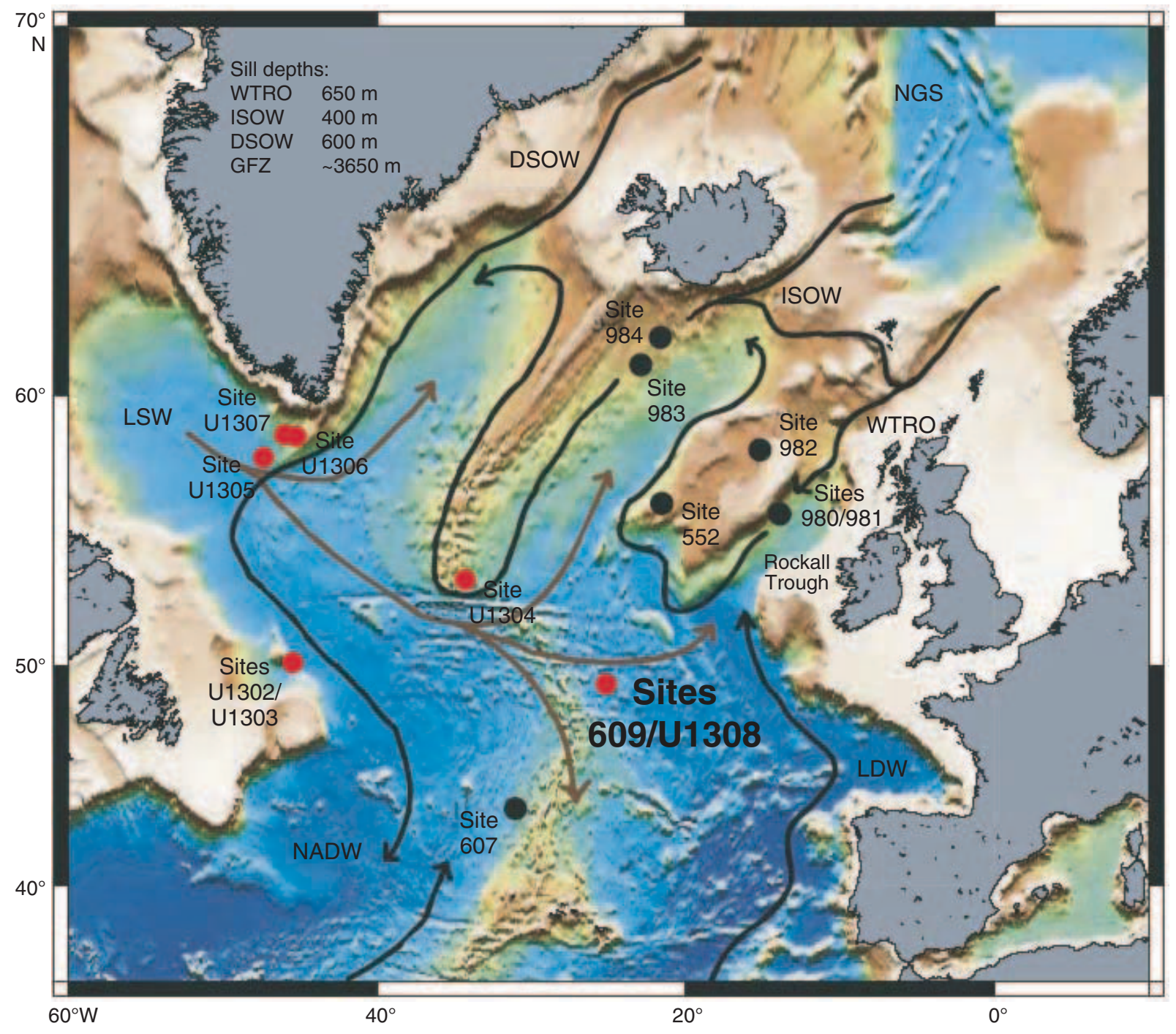


Figure F2. Stratigraphic distributions of marker species of each datum found at Site U1308. Circled numbers = stratigraphic boundaries of magnetic polarity and positions of each datum. PDB = Peedee belemnite, $\mathrm{J}=\mathrm{Jara}-$ millo, $\mathrm{CM}=$ Cobb Mountain, $\mathrm{O}=$ Olduvai. $\mathrm{FO}=$ first occurrence, $\mathrm{LO}=$ last occurrence.

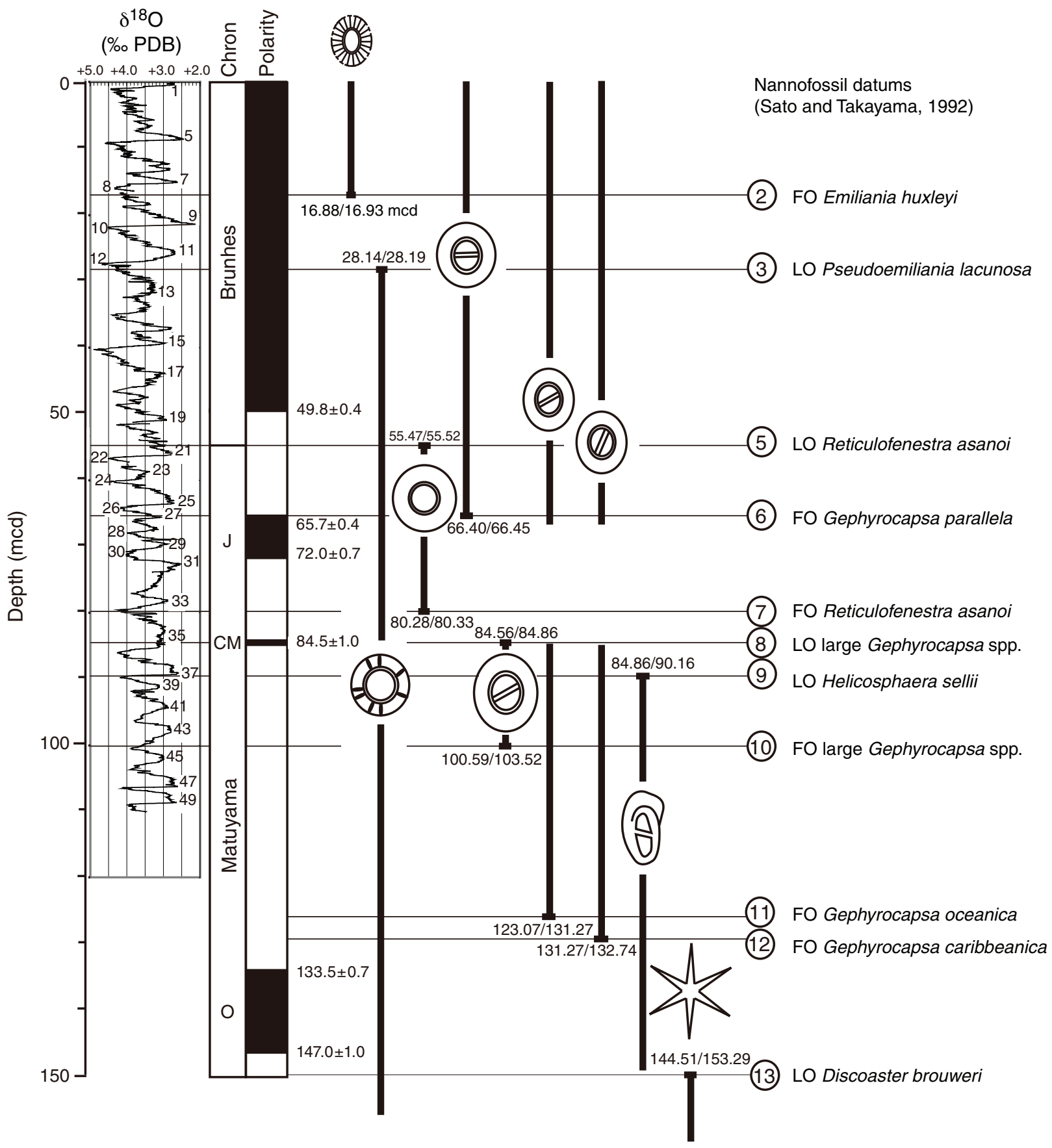


Figure F3. Summary of calcareous nannofossil datum events versus time interval from 0 to $2.0 \mathrm{Ma}$, Site U1308. $\mathrm{PDB}=$ Peedee belemnite, $\mathrm{J}=$ Jaramillo, $\mathrm{CM}=$ Cobb Mountain, $\mathrm{O}=$ Olduvai. $\mathrm{FO}=$ first occurrence, $\mathrm{LO}=$ last occurrence.

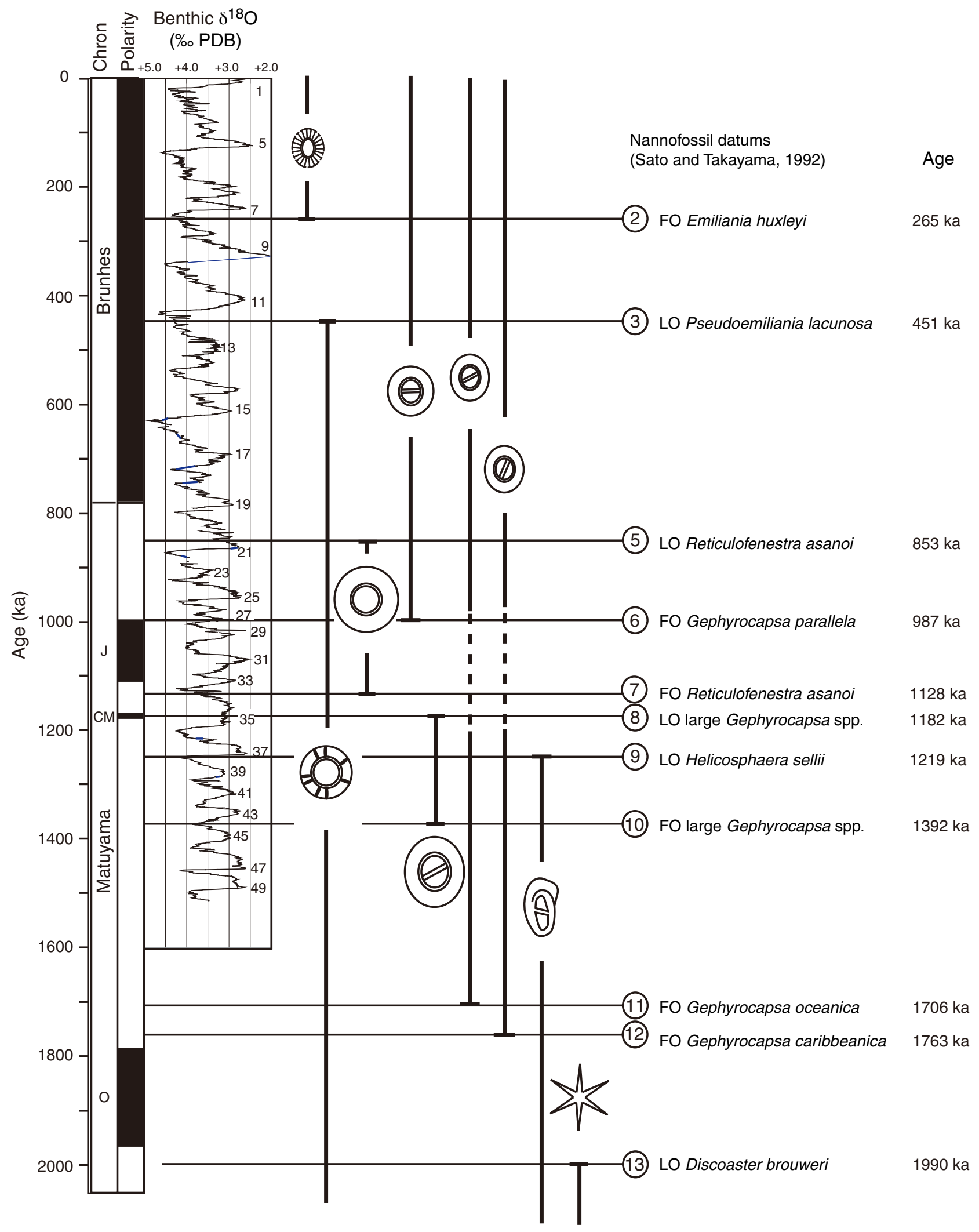


Figure F4. Relationship between stratigraphic position of nannofossil Datums 2 (first occurrence of Emiliania huxleyi) and 3 (last occurrence of Pseudoemiliania lacunosa) and oxygen isotope stratigraphy, Site U1308. PDB = Peedee belemnite, MIS = marine isotope stage.

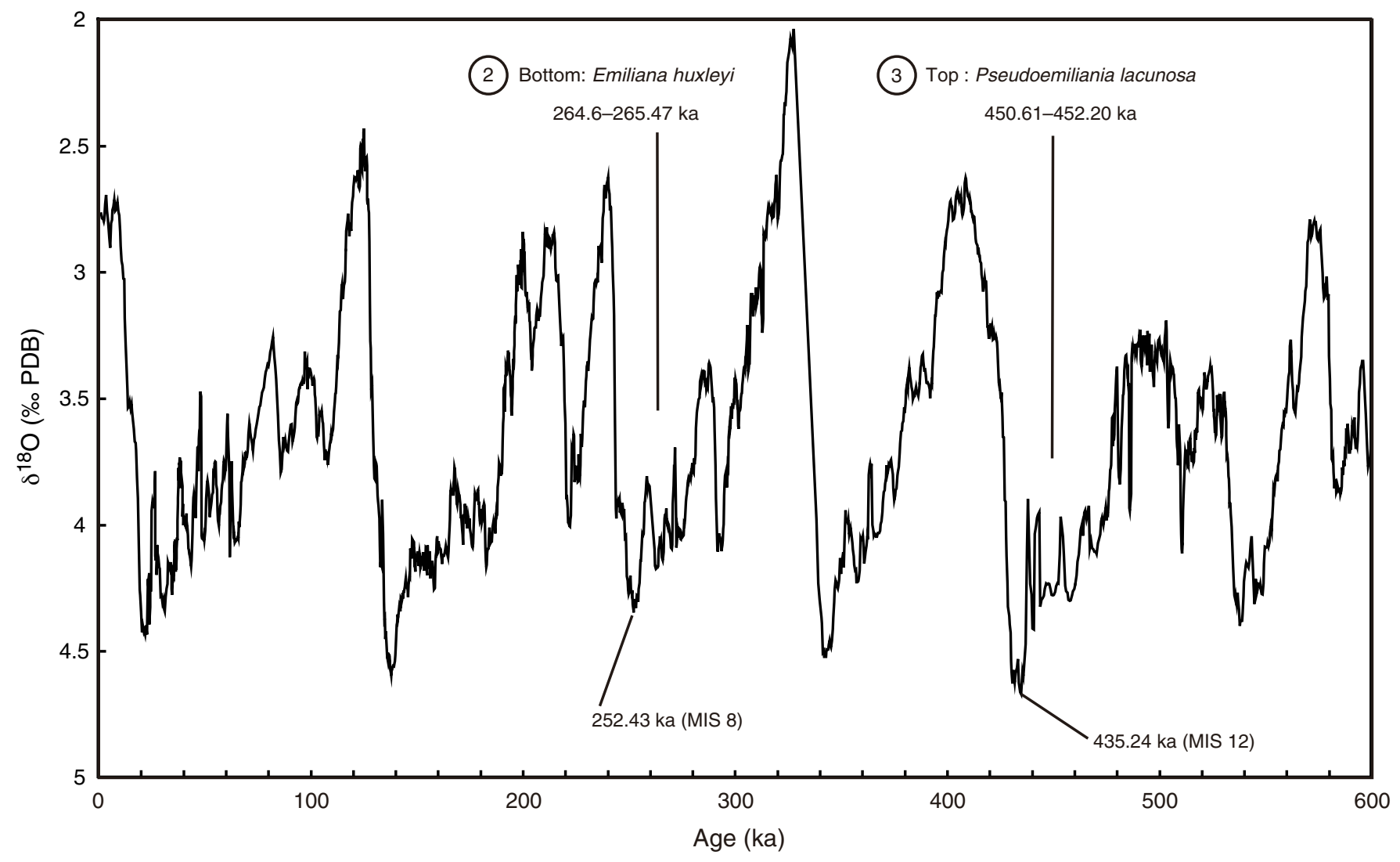


Table T1. Calcareous nannofossil datum stratigraphic positions and ages, Site U1308. (See table notes.)

\begin{tabular}{clccccc}
\hline \multirow{2}{*}{$\begin{array}{c}\text { Datum } \\
\text { number }\end{array}$} & Calcareous nannofossil datum & $\begin{array}{c}\text { Depth } \\
(\mathrm{mcd})\end{array}$ & $\begin{array}{c}\text { Age } \\
(\mathrm{ka})\end{array}$ & MIS & Chron/Subchron & $\begin{array}{r}\text { Age } \\
(\mathrm{ka})\end{array}$ \\
\cline { 3 - 6 } & FO Emiliania huxleyi & $16.88-16.93$ & $264.64-265.47$ & 8 & Brunhes & 265 \\
2 & LO Pseudoemiliania lacunosa & $28.14-28.19$ & $450.61-452.20$ & 12 & Brunhes & 451 \\
3 & LO Reticulofenestra asanoi & $55.47-55.52$ & $852.42-854.05$ & 21 & Brunhes Jaramillo & 853 \\
5 & FO Gephyrocapsa parallela & $66.40-66.45$ & $987.34-987.98$ & 27 & Top Jaramillo & 987 \\
6 & FO Reticulofenestra asanoi & $80.28-80.33$ & $1128.3-1128.7$ & 34 & Jaramillo Cobb Mountain & 1128 \\
7 & LO Gephyrocapsa spp. (large) & $84.56-84.86$ & $1180.5-1184.3$ & 35 & In Cobb Mountain & 1182 \\
9 & LO Helicosphaera sellii & $84.86-90.16$ & $1184.3-1255.2$ & 38 & Cobb Mountain Olduvai & 1219 \\
10 & FO Gephyrocapsa spp. (large) & $100.59-103.52$ & $1371.3-1412.8$ & 44 & Cobb Mountain Olduvai & 1392 \\
11 & FO Gephyrocapsa oceanica & $123.07-131.27$ & - & - & Above Olduvai & $1706^{*}$ \\
12 & FO Gephyrocapsa caribbeanica & $131.27-132.74$ & - & - & Above Olduvai & $1763^{*}$ \\
13 & LO Discoaster brouweri & $144.51-153.29$ & - & - & Below Olduvai & $1990^{*}$ \\
\hline
\end{tabular}

Notes: Datum numbers by Sato and Takayama (1992). MIS $=$ marine isotope stage. FO = first occurrence, $\mathrm{LO}=$ last occurrence, $-=$ no data, ${ }^{*}=$ based on magnetostratigraphy. 